\title{
Impact of Human Settlement on Land Use/Land Cover Changes in the Middle River Njoro Sub Watershed in Kenya
}

\author{
Zachary Gichuru Mainuri \\ Egerton University, Crops, Horticulture and Soils Department, \\ P.O Box 536 Egerton, Njoro
}

\begin{abstract}
This study investigated the use of remote sensing and GIS in evaluating the impacts of human settlement on land use /Land cover changes. The study also investigated the drivers behind the change in the middle of River Njoro sub watershed for a period of 27 years. Drivers of land use change were captured by the use of DPSIR model where Drivers (D) represented human needs, Pressures (P), human activities, State (S), the ecosystem, Impact (I) services from the ecosystem and Response (R), the decisions taken by land users. Land sat MSS and Land sat ETM+ (path 185, row 31) were used in this study. The Land sat ETM+ image (June 1987, May, 2000 and July, 2014) was downloaded from USGS Earth Resources Observation Systems data website. Remote sensing image processing was performed by using ERDAS Imagine 9.1. Three land use/land cover (LULC) classes were established as Human settlement, forest and shrub land. Severe land cover changes was found to have occurred from 1987-2000, where human settlement increased by $52 \%$, shrub land reduced by $19 \%$, and forestry reduced by $72 \%$. In the year $2000-2014$, human settlement increased by $121 \%$, shrub land reduced by $45 \%$, and forestry reduced by $64 \%$. Forestry and shrub land were found to be consistently reducing while human settlement was increasing. It was evident from the images that the LULC changes with corresponding soil quality deterioration mostly occurred in the upper and middle parts of the Middle river Njoro sub watershed which were initially under forest. To minimize the risk of vegetation destruction and soil degradation, it will be necessary to identify socioeconomic safety nets and initiate restoration of the environment to original pre- catastrophe status.
\end{abstract}

Keywords: watershed. Land uselland cover change, Landsat imagery, Geographic Information System

\section{Introduction}

Settlement can be observed directly in the field or by remote sensing. Information collected on land use in form of settlement require the integration of natural and social scientific methods (expert knowledge, interviews with land managers) to determine which human activities resulting from settlements that are occurring in different parts of the landscape. As a result, scientific investigation of the causes and consequences of land use/land cover change (LULCC) requires an interdisciplinary approach integrating both natural and social scientific methods, which has emerged as the new discipline of land-change science. Land use /Land cover (LULC) is continuously changing in the Middle River Njoro ecosystem, thereby threatening sustainability and livelihood systems of the people. Human population increase is causing great pressure to the natural environment resulting in increasing conflict between different human activities and the need for biodiversity conservation. Settlements and other biodiversity modifications have resulted in deforestation, biodiversity loss, global warming and increase of natural disaster like flooding (Fan et al, 2007, Dwivedi, et al, 2005).Land use/land cover change in most or all cases is associated with environmental problems. Therefore, available data on LULC changes can provide critical input to decision-making of environmental management and planning the future (Fan, et al, 2010, Prenzel, 2004). The growing population and increasing socio-economic necessities creates a pressure on land use/land cover. This pressure results in unplanned and uncontrolled changes in LULC (Seto, et al, 2002). The LULCC alterations or change in the state of the ecosystem are generally driven by pressures resulting from mismanagement of agricultural, urban, and forest lands which lead to severe environmental impacts such as landslides that require a response to abate disaster.

The driver's - pressure - state - impact - response (DPSIR) framework is a causal chain where the driving forces of LULCC consist of any natural (biophysical) or human-induced (socio-economic) factors like settlement that can lead to environmental pressures. The demand for agricultural land, energy, water, food, transport and housing can serve as examples of driving forces (Giupponi, 2002; Kristensen, 2004; Wood and van Halsema, 2008). Pressures consist of the driving forces' consequences on the environment such as the exploitation of resources (land, water, minerals, fuels, etc.), 
pollution and the production of waste or noise (Wood and van Halsema, 2008). As a result of pressures, the 'state' of the environment is affected; that is, the quality of the various natural resources (air, water, soil, etc.) in relation to the functions that these resources fulfill. The 'state of the environment' is thus the combination of the physical, chemical and biological conditions. The support of human and non-human life as well as the depletion of resources can serve as pertinent examples (Kristensen, 2004). Changes in the state may have an impact on human health, ecosystems, biodiversity, amenity value and financial value. Impact may be expressed in terms of the level of environmental harm and finally, the responses demonstrate the social efforts to solve the problems identified by the assessed impacts, e.g. policy measures, and planning actions (EEA, 1999; Giupponi, 2002; Kristensen, 2004; Wood and van Halsema, 2008).To date, DPSIR has been proved as a valuable tool that describes the relationships between the origins and consequences of environmental problems (Leka et al., 2005), it provides a significant fraction of the necessary environmental information (EUROSTAT, 1999), it facilitates decision making (Tscherning et al., 2012) and promotes the core essence of environmental sustainability (Reed et al., 2006). As a result, it has been applied in numerous research efforts including Water Resources Management of various scales as well as in a series of international and multidisciplinary research projects as the main analysis tool (Tscherning et al., 2012).

The middle River Njoro sub Watershed has been undergoing a new phase of rapid land use change to accommodate the increasing rural and urban human settlements. There is therefore need to understand how land use changes affected the environmental sustainability of the study area. This study was therefore aimed at establishing the impact of human settlement on land cover/land use change and its influence on land use decisions in the middle River Njoro sub watershed.

\section{Study Area}

Njoro town is located in Nakuru County on the eastern edge of the Mau Forest Complex, the largest single forest blocks in Kenya. The area lies between the forest and Lake Nakuru National Park, a world famous flamingo habitat. The greater Nakuru District is situated between $35^{\circ} 28^{\prime}-35^{\circ} 36^{\prime}$ E longitude and $0^{\circ} 13^{\prime}-1{ }^{\circ} 10^{\prime} S$ latitude. Most of the new settlers were originally pastoralists but are now practicing agro-pastoralists or keeping animals and practising crop farming. In addition to farming, they are using cleared forest areas for grazing livestock, mainly cattle, sheep and donkeys. Besides subsistence farming, these farmers also keep dairy animals and grow wheat as a cash crop. Smaller farms are interspersed with a few remaining large scale farms from the colonial era, including Egerton University's Ngongogeri commercial farm. Urban centres in the middle zone include Njokerio which is around Egerton University Campus and Njoro Township.

The area of study covers about 8,170 $\mathrm{Ha}$ and lies between latitudes $0^{\circ} 15^{\prime} \mathrm{S}$ and $0^{\circ} 25^{\prime} \mathrm{S}$ and longitudes of $35^{\circ} 50^{\prime} \mathrm{E}$ and $36^{\circ} 00^{\prime} \mathrm{E}$ (Figure 1). The whole watershed has a population of about three hundred thousand $(300,000)$ people with more than three thousand (3000) individual farm holding units (Baldyga, et al., 2003). However, according to Kenya National Bureau of Statistics, Njoro Sub County registered a population of 23,551 people having grown by $3 \%$ from a population of 22, 845 people in 1999 (KNBS, 2009). Based on the same growth rate, the watershed population may have also grown to 309,000 people with may be 3100 households. Due to the heavy settlement in the middle watershed, it is estimated to be home to about 2000 farm holding units in an area of more than 8,000 hectares with slopes ranging from $<2$ to $>$ and soils that are predominantly volcanic clay loam except near the lake where silt clay dominates (Mainuri and Owino, 2013).

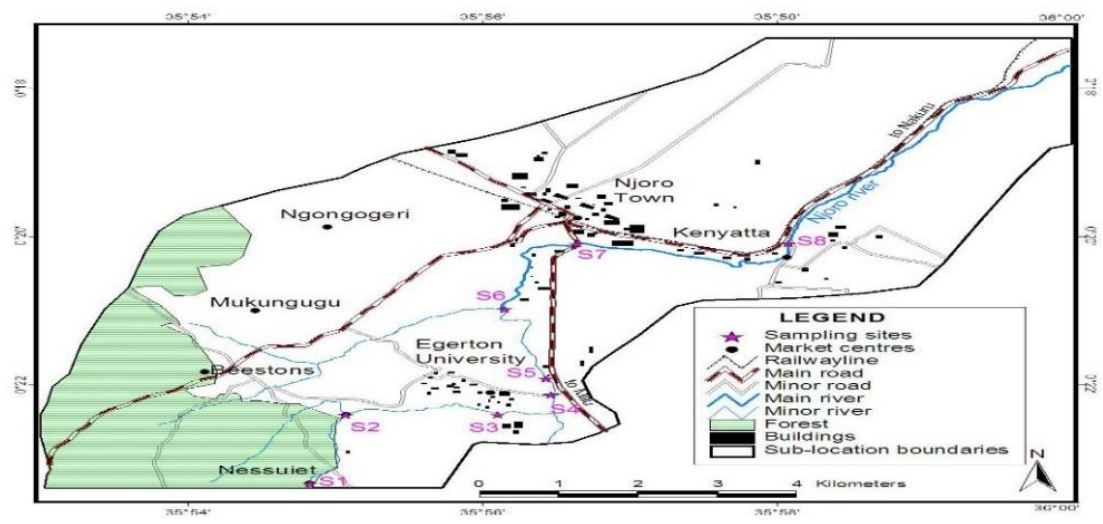

Figure 1: Middle River Njoro Watershed (Source: Mainuri and Owino, 2014) 


\subsection{Methods}

A baseline survey at household-level encompassing socio-economic changes and impacts of land use activities in the middle River Njoro Watershed was established. Additionally, information on factors influencing land use decisions, productivity factors and change in economic activities were sought through use of a questionnaire. The middle River Njoro sub watershed household survey was to target an area of approximately 8000hectares. Three Landsat scenes were selected $(1987,2000$ and 2014) for this study. These dates captured the major excision and settlement changes that have taken place in the watershed. Effort was made to acquire imagery that corresponds with major land use/land cover changes within this period.

The study utilized 200 questionnaires which were administered to homesteads that were initially identified at random on both sides of the river. The questionnaires were subjected to scrutiny for completeness and consistency in question answering and the way they addressed the various issues intended to be captured. The questionnaires were sorted out and entered into the SPSS (version 20) work sheet. With the descriptive and categorical nature of most of the questions, simple descriptive analysis was done using SPSS and inferential statistics performed based on the results.

\subsection{Land use field data}

Data on the driving factors that influence land use decisions in the Middle River Njoro sub watershed drainage basin was gathered through semi-structured interviews with the farmers (land owners) and six (6) key informants selected at random based on the their areas of operation including an agriculturist, environmentalist, social economist and NGOs in the region. Local group officials such as self-help groups, Friends of River Njoro and Water Resource Users Association (WRUA), were also interviewed concerning land use history and the perceived processes driving land use in the area.

\subsection{Image classification}

Land sat MSS and Land sat ETM+ (path 185, row 31) were used in this study. The Land sat ETM+ images (June 1987, May, 2000 and July, 2014) were downloaded from USGS Earth Resources Observation Systems data. The dates of both images were chosen to be as closely as possible in the same vegetation season. All visible and infrared bands were included in the analysis. Remote sensing image processing was performed using ERDAS Imagine 9.1.Five LULC classes were established as commercial farms, forest, settlement, subsistence farms, and shrub land. Three dated Land sat images (1987, 2000, and 2014) were compared using supervised classification technique. In the supervised classification technique, three images with different dates were independently classified. A Supervised classification method was carried out using training areas. Maximum Likelihood Algorithm was employed to detect the land cover types in ERDAS Imagine9.1.

\subsection{Analysis of the Driving Forces of Land Use using DPSIR model}

The DPSIR conceptual framework is a causal chain consisting of five elements; Drivers (human needs), Pressures (human activities), State (the ecosystem), Impact (services) and Response (decisions) which was used as a means to organize the many social, economic and ecological interactions in the sub watershed. Assessment of driving forces behind land use/land cover change (LULCC) was done to capture past patterns and also be able to forecast future patterns. Driving forces on LULCC captured in the survey included most of the factors that influenced human activity, including population increase, poverty, land tenure and markets. Also other underlying factors like local culture, food preference were found to influence the decisions made. Economics or the demand for specific products and financial incentives were also reported to greatly influence the pattern of production. Environmental conditions like soil quality, terrain, moisture availability, land policy and development programs such as agricultural programs, road building, zoning and feedbacks between these factors which included past human activity on the land such as land degradation, irrigation and roads played a major role in the decisions that people made.

\subsection{Results}

It was observed from the survey that 50 percent of the respondents had obtained up to primary education, while $20 \%$ percent had not obtained any formal education. A lower proportion (33\%) had obtained secondary and post secondary level of education. 70 percent of the respondents had primary level education and below. The finding indicates that most of the respondents in the middle river Njoro sub watershed had low formal education and this affected the way in which they responded to new information on resource conservation and how they also received innovative ideas. The respondents were interviewed on the changes in natural vegetation and human settlement. $73 \%$ of the respondents agree that human 
settlement has been increasing while $27 \%$ of them feel that human settlement has not been significant. $93 \%$ of the watershed inhabitants have observed massive land use changes taking place with $7 \%$ not feeling that there has been any noticeable change in land use. This possibly could be that they have recently settled in the area and since they settled there has been no change. Climate change impacts resulting from human settlement have been felt by $31 \%$ of the people with a bigger population of $69 \%$ having not experienced any effects of climate change. The pressures exerted by the society through waste disposal, over cultivation and deforestation may have led to unintentional or intentional changes in the state of the ecosystem. However, only $4 \%$ of the respondents had observed any pollution or degradation of the ecosystem with a huge population of $96 \%$ not feeling or not being aware of the impacts possibly because they had recently purchased the land.

It emerged from the study findings that the biggest proportion (60\%) of the land was bought by the current owners. A number of respondents had inherited the land from their fore parents comprising about $20 \%$ of the total. There were also cases of people (15\%) allocated land by the government while the remaining $5 \%$ had acquired their pieces of land through buying shares in cooperative societies (Figure 2).



\section{Figure 2: Land tenure}

The study also established that most of the land was under cultivation when the current owners acquired as portrayed by $31.7 \%$ of the responses. This was closely followed by grass cover which formed $26.6 \%$ of the total responses. A significant $19 \%$ reported that the land area was under indigenous trees when they initially moved in, while a $15.4 \%$ response exhibited presence of exotic trees. However, only $7.3 \%$ of the total responses reported the presence of soil and water conservation structures on the land during initial settlement period (Table 1).

Table 1: Nature/ state and extent of Land cover during acquisition by current owners

\begin{tabular}{llll}
\hline \multirow{2}{*}{ Land Use/ Cover } & \multicolumn{2}{l}{ Responses } & Percent of Cases \\
\cline { 3 - 4 } & $\mathrm{N}$ & Percent & \\
\hline Presence of soil and water conservation structures & 24 & $7.3 \%$ & $12.9 \%$ \\
Under cropping & 105 & $31.7 \%$ & $56.5 \%$ \\
Under grass cover & 88 & $26.6 \%$ & $47.3 \%$ \\
Under indigenous trees & 63 & $19.0 \%$ & $33.9 \%$ \\
Under exotic trees & 51 & $15.4 \%$ & $27.4 \%$ \\
Total & 331 & $100.0 \%$ & $178.0 \%$ \\
\hline
\end{tabular}

An interview was carried out on some key informants concerning the land use activities that have been observed over the period of study (Table 2). The respondents reported that the main environmental impacts were indicated by a general 
increase in agricultural activities on riparian zones. This has emanated from pressures exerted by the increase in the number of people settling along the river Njoro. The main economic activity creating impacts to the ecosystem that was reported by these people was usually farming by the many people settling in the sub watershed which has resulted in the reduction of natural vegetation. However, the state of the ecosystem has remained a bit stable despite the heavy human settlement due to agro forestry and scattered natural vegetation that has contributed to the forest which is thriving in some parts of the ecosystem. The impacts of human settlement had altered the state of the ecosystem with most farms being seriously affected by soil erosion as most farmers were not observing any conservation measures. Hence, soil erosion was found to be notably rampant in Lare and Nessuit areas which have higher slopes with $70 \%$ of the respondents reporting severe erosion in the steeper slopes, $20 \%$ reported severe erosion on gentle slopes and $10 \%$ on flat grounds, while $20 \%$ of the people reported moderate erosion on steep areas, $69 \%$ reported moderate erosion on gentle slopes and $11 \%$ on flat grounds. $80 \%$ of the respondents reported no erosion on gentle slopes and $20 \%$ reporting no erosion on flat areas. Nobody gave any evidence of no erosion on steep slopes (Table 2).

Table 2: Level of soil Erosion

\begin{tabular}{|l|l|l|l|}
\hline Slope of the land & Level of erosion & No erosion \\
\hline & severe & moderate & 0 \\
\hline Steep & 70 & 20 & 80 \\
\hline Gentle & 20 & 69 & 20 \\
\hline Flat & 10 & 11 & \\
\hline
\end{tabular}

As a result of no proper land ownership, most people are shy to invest in long term development activities and majorities are sluggish or unable apply any resource conservation measures. Driving forces on land use and conservation of natural vegetation included most of the factors that influenced human activity that exerted pressure on the ecosystem, including population increase, poverty, land tenure and markets. Underlying factors that drive actions like food preference demand for specific products, financial incentives and environmental state indicators such as soil quality, terrain and moisture availability played a great role in altering the land cover of the area. Increasing land use/cover changes were observed in the middle river Njoro watershed ecosystem which had more settlements over the last twenty seven (27) years. These changes resulted from a number of factors, but mainly related to habitat loss due to agricultural encroachment and human settlement. Information about changing patterns of land use/cover through time and the factors influencing such changes have been captured in the change detection maps of 1987, 2000 and 2014 and the results summarized in Table 4.The Long et al., (2010) formula computed the rate of change within the three periods (T1, T2, and T3).

$$
\Delta=\left\langle\frac{A 2-A 1}{A 1} \times 100\right\rangle \div\langle T 2-T 1\rangle
$$

Where:

. = Average annual rate of change $(\%)$

$\mathrm{A} 1=$ Amount of land cover type in time $1(\mathrm{~T} 1,1987)$

$\mathrm{A} 2=$ Amount of land cover type in time $2(\mathrm{~T} 2,2000)$

$\mathrm{A} 3=$ Amount of land cover type in time $3(\mathrm{~T} 3,2014)$

Table 3: Change detection

\begin{tabular}{|l|l|l|l|l|l|}
\hline Class Type & $\begin{array}{l}1987 \text { Area } \\
\text { Hectares T1 }\end{array}$ & $\begin{array}{l}2000 \\
\text { Hectares T2 }\end{array}$ & $\begin{array}{l}2014 \\
\text { Hectares T3 }\end{array}$ & $\begin{array}{l}\Delta \mathrm{Ha} \\
1987-2000 \\
\text { T1-T2 }\end{array}$ & $\begin{array}{l}\Delta \mathrm{Ha} \\
2000-2014 \\
\text { T2-T3 }\end{array}$ \\
& & & & \\
\hline
\end{tabular}




\begin{tabular}{|l|l|l|l|l|l|}
\hline Forest & 1460.898 & 405.351 & 145.712 & $-72 \%$. & $-64 \%$ \\
\hline Settlement & 437.403 & 664.109 & 1470.364 & $+52 \%$, & $+121 \%$ \\
\hline Shrub land & 849.281 & 687.820 & 373.150 & $-19 \%$, & $-45 \%$ \\
\hline
\end{tabular}

From the study, it is evident that natural vegetation which was indicated by forest and shrub land (Table 5) has reduced over the period the respondents have resided in the area. The result from image processing and analysis for the years 1987,2000 and 2014 portrays a general reduction due to settlements in both forests and shrub lands within the study area Figure $3(a, b, c)$.
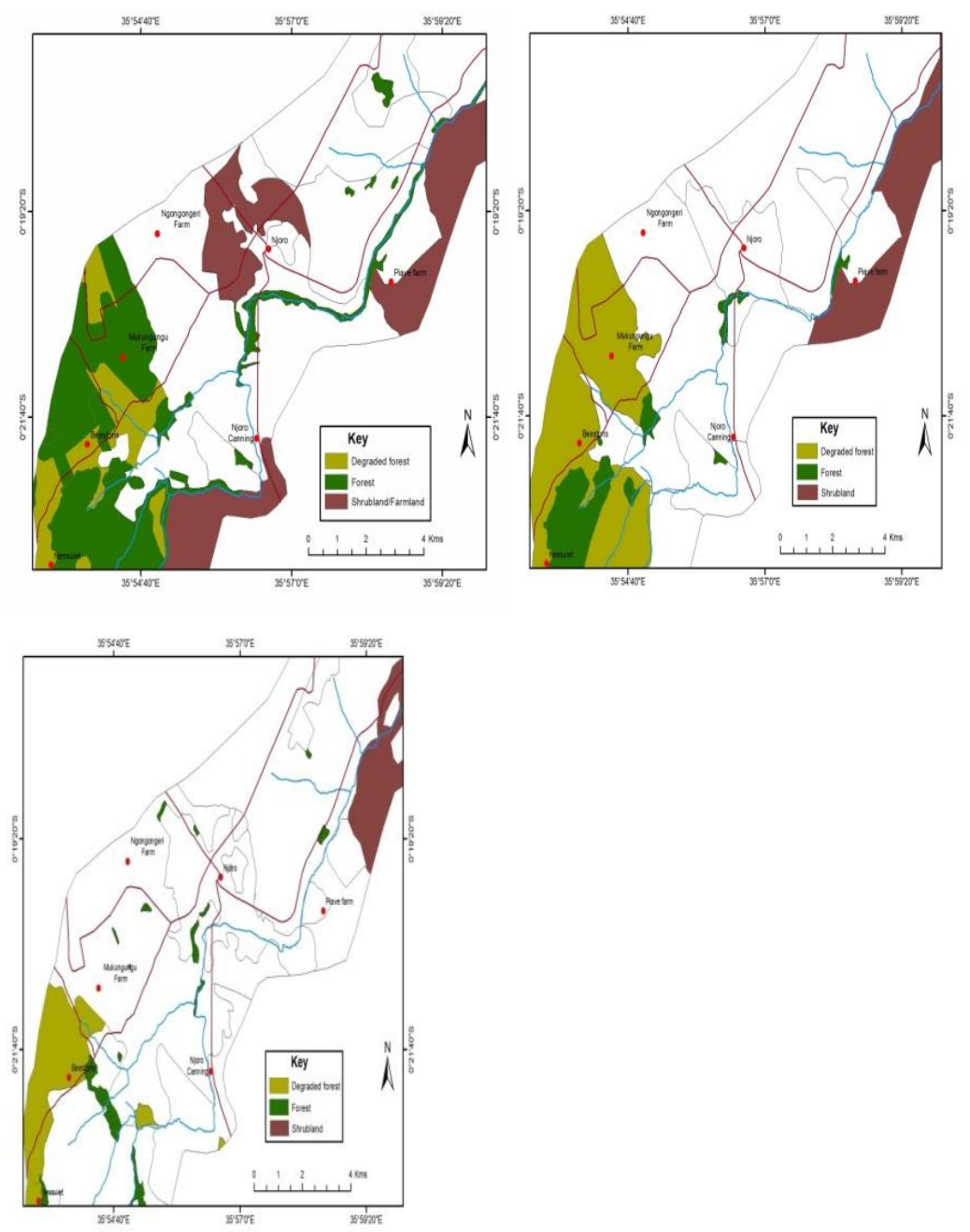

1987

(b) 2000

(c) 2014

Figure 3: Reduction of Forests and Shrub Lands over the period of study. 
We can therefore say that deforestation has been witnessed in the study area for the last two decades due to land use patterns. These patterns resulting from cultivation and human settlement stood out to be the major driving forces that have led to the reduction in natural vegetation cover in these areas, each constituting $33 \%$ and $30.9 \%$ of the total responses respectively. Other activities included charcoal burning, infrastructural development, and grazing and commercial timber production resulting from the growing population. The population has for the last two decades been growing. Owing to this, respondents' feedback shows that a significant increase in human settlement has been witnessed in the areas covered by the study. An assessment of the values obtained from image analysis of the area, show that there has been an almost four times increase (from about 437 ha in 1987 to 1500 ha in 2014) in the human settlements Figure $4(a, b, c)$

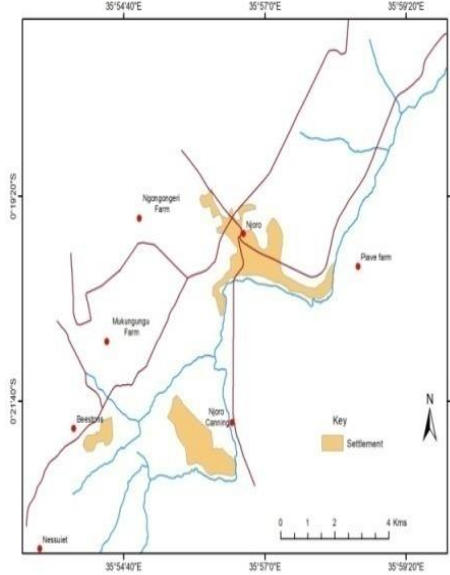

a) 1987



(b) 2000

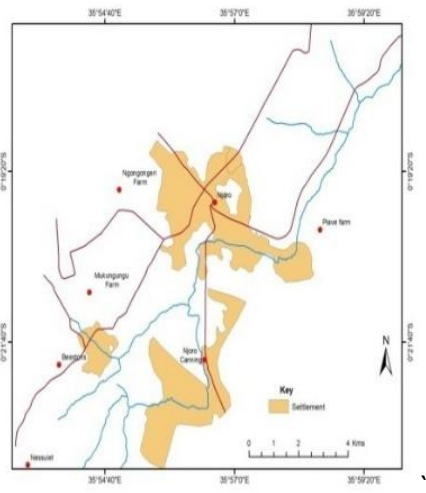

(c) 2014 .

\section{Figure 4 : Human Settlement Variation in the Study for the Period 1987 to 2014}

One of the most fundamental and characteristic nature of people is the movement from place to place which most of the time results in change of residence. This phenomenon, otherwise referred to as migration, has played a vital role in elevating the number of people who have settled in the area for the past twenty or more years. Migration was a factor which explained why human settlements in these areas have grown over time greatly reducing the available size of land for each family. It is evident from the responses that the largest piece of land was 15 acres while the minimum land size was 0.125 acres giving a range value of 14.875 acres (Table 4).

Table 4: Land size and duration of ownership

\begin{tabular}{llllll}
\hline Items & $\mathrm{N}$ & Range & Minimum & Maximum & Mean \\
\hline Land size & 200 & 14.875 & 0.125 & 15.000 & 3.07661 \\
$\begin{array}{l}\text { Duration the owner has lived on the } \\
\text { land }\end{array}$ & 200 & 65.0 & 1.0 & 66.0 & 16.817 \\
\hline
\end{tabular}

On average, each respondent owned about 3.08 Acres of land. We had both long term occupants of the land with a period of about 66 years and some quite new occupants who had settled for about 1 year. This gave a range of 65 years which is vital in explaining the changes in the land use/ cover that has been witnessed in this area of study.

\subsection{Conclusions and Recommendation}

The factors driving land use decisions in the middle River Njoro watershed include human settlement and economic developments in the watershed community, and the corresponding changes in lifestyles, overall levels of consumption and production patterns. These drivers have exerted pressure to the ecosystem in form of waste disposal, over cultivation, 
overgrazing and deforestation. These pressures have caused negative changes to the ecosystem which have caused heavy impacts mainly through removal of natural vegetation.

The removal of natural vegetation in the middle River Njoro sub watershed has resulted in the decreasing of the forest area by 1314 hectare and shrub land by 475 hectares with settlement increasing by 1032 hectares.

Land use/land cover changes mostly occurred in the upper parts of Middle river Njoro sub watershed with higher slopes and the middle and lower parts which have gentle and nearly flat slopes experiencing low or no change at all.

The integration of remote sensing and GIS was found to be effective in monitoring and analyzing land cover patterns and also in evaluating the influence of human settlement on land use change for future land development projects by the residents of study areas.

The residents are therefore recommended to develop responses to rehabilitate the degraded environment through soil and water conservation, reducing land use/land cover change (LULCC), choice of crops and crop rotation in order to mitigate the negative outcomes of the ecosystem changes.

\section{References}

[1] Baldyga, T.J. (2003). Assessing Land cover Change Impacts in Kenya's River Njoro Watershed using remote sensing and Hydrological Modeling. MSc Thesis (unpublished) submitted to the Department of Renewable Resources at the University of Wyoming. Laramie, U.S.A.

[2] Dwivedi, R.S.; K.Sreenivas; K.V.Ramana, (2005). Land-use/land-cover change analysis in part of Ethiopia using Landsat Thematic Mapper data. International Journal of Remote Sensing 2005, 26 (7), 1285-1287.

[3] European Environment Agency (1999). Environmental Indicators: Typology and Overview. Technical Report No. 25 , Copenhagen.

[4] EUROSTAT (1999). Environmental Pressure indicators for the EU. First Edition. Theme 8: Environment and Energy.

[5] Fan, F.; Weng, Q.; Y. Wang, (2007). Land use land cover change in Guangzhou, China, from 1998 to 2003, based on Landsat TM/ETM+ imagery. Sensors 2007, 7, 1323-1342.

[6] Fan, F., Q.Weng, and Y.Wang, (2010). Land use and land cover change in Guangzhou, china, from 1998 to 2003, based on Landsat TM /ETM+ imagery Sensors 7, 1323-1342

[7] Government of Kenya, Kenya National Bureau of Statistic (KNBS) (2009). Kenya National Population and housing census, 2009.

[8] Guerschman J.P.; J.M.Paruelo,; C.D.Bela,; M.C.Giallorenzi,; F.Pacin, (2003). Land cover classification in the Argentine Pampas using multi-temporal Landsat TM data. International Journal of Remote Sensing 2003, 24, 3381-3402.

[9] Giupponi C. (2002). From the DPSIR reporting framework to a system for a dynamic and integrated decision making process. International MULINO Conference on "European policy and tools for sustainable water management" Island of San Servolo, Venice, Italy, November 21-23.

[10] Kristensen P. (2004). The DPSIR Framework. National Environmental Research Institute, Denmark. European Topic Centre, European Environment Agency.

[11] Leka A., Goumas S. and C. Cassios, (2005). The Modern Role and Importance of Using Environmental Indicators as a Key Tool in Environmental Management, Heleco '05, Greek Technical Chamber, Athens, Greece.

[12] Mainuri, Z.G., and J.O.Owino, (2013). Effects of land use and management on aggregate stability and hydraulic conductivity of soils within River Njoro Watershed in Kenya. International Journal of Soil and water conservation research. Vol.1 No.2 pp. $80-87$. 
[13] Prenzel, B.(2004). Remote sensing-based quantification of land-cover and land-use change for planning.Progress in Planning 2004, 61, 281-299.

[14] Reed M.S., E.D.G. Fraser and A.J. Gougill, (2006). An adaptive learning process for developing and applying sustainability indicators with local communities, Ecological Economics, 59, 406-418.

[15] Seto, K.C., C.E.Woodcock, C.Song, X.Huang, J.Lu, R.K. Kaufmann, (2002).Monitoring land use change in the Pearl River Delta using Landsat TM. International Journal of Remote Sensing 2002, 23, (10), 1985-2004

[16] Tscherning K., K.Helming, B.Krippner, S.Sieber and Y.Gomez, S.Paloma, (2012).Does research applying the DPSIR framework support decision making?, Land Use Policy, 29(1), 102-110. United Nations (UN), 1996. Indicators of sustainable development: Framework and Methodologies. Report. 428 